\title{
Mojca Canjko
}

\section{O stikih Mikencev in Hetitov}

\section{UVOD}

Začetek mikenske kulture zaznamuje izoblikovanje močnih in premožnih socio-političnih elit na različnih področjih celinske Grčije med 17. in 16. stol. pr. n. št. V obdobju palač (od 1450 do 1200 pr. n. št.) je mikenska civilizacija tradicionalno opisana kot splet politično neodvisnih državic $\mathrm{z}$ administrativnimi centri v Mikenah, Pilosu, Tirinsu, Tebah, Knososu idr. Mikenske najdbe iz tega časa so poleg tega raztresene od egejskih otokov, obal Anatolije in Levanta, pa vse do Egipta. V novejšem času so zato Mikenci opisani kot entiteta, ki se je od celinske Grčije raztezala vse do otokov Egejskega morja in celo do (verjetno) edinega centra mikenske kulture v zahodni Anatoliji - kasnejšega Mileta. ${ }^{1}$

Indoevropsko ljudstvo Hetitov je v 2. tisočletju pr. n. št. živelo v Mali Aziji na področju današnje osrednje Turčije. Med 16. in začetkom 12. stol. pr. n. št. so bili organizirani v državi, ki je bila na vrhuncu politične in vojaške moči enakovreden partner celo staremu Egiptu. ${ }^{2}$ Prvotno je bila hetitska država pravzaprav zveza mestnih državic $\mathrm{z}$ upravno samostojnostjo in različnimi kralji, temu je sledilo obdobje organizacijskih sprememb, vzponov in padcev, v mladohetitskem obdobju (od 1380 do 1220 pr. n. št.) pa so bili povezani v močno centralizirano državo. Središče dežele Hatti je bilo v osrednji Anatoliji, kjer se je (večino časa) nahajalo tudi njeno glavno mesto Hattuša (današnji Boğazköy). Hatti je bila kopenska država, brez dostopa do morja. S pomočjo vazalnih držav in davkov obveznih področij so si Hetiti prizadevali tudi za utrditev in ohranitev oblasti na področju zahodne Anatolije in obalah Egejskega morja. ${ }^{3}$

1 Gl. Kelder, The Kingdom of Mycenae.

$2 \mathrm{O}$ tem priča npr. mirovna pogodba med hetitskim kraljem Hattušilijem III. in Ramzesom II., kopija katere je danes razstavljena v palači Združenih narodov v New Yorku.

3 Gl. Collins, The Hittites and Their World, 21-90. 
O naravi stikov med Hetiti in Mikenci na "periferiji« obeh kultur je mogoče (ob predpostavki, da v hetitščini izpričano ime Ahhiyawa označuje Mikence) sklepati na osnovi pisnih in arheoloških virov. Prispevek zato prinaša pregled in interpretacijo hetitskih besedil z omembami Ahhiyawe, arheoloških virov o Mikencih na področju Anatolije in Hetitih na področju Egejskega morja, nato shematično prikaže naravo stikov med Mikenci in Hetiti in opozori na vprašanja, ki jih prinaša identifikacija Ahhiyawe z mikenskim svetom.

\section{LOKACIJA AHHIYAWE}

V hetitskih besedilih izpričano krajevno ime Ahhiyawa (starejše Ahhiya) je z Mikenci celinske Grčije (torej Ahajci) leta 1924 identificiral švicarski znanstvenik E. Forrer, ki je predlagal tudi povezave med specifičnimi posamezniki in krajevnimi imeni $\mathrm{v}$ teh besedilih $\mathrm{z}$ imeni v grških legendah o trojanski vojni. ${ }^{4}$ Forrerjevi predlogi so doživeli različne reakcije, od sprejemanja do zavračanja. Tisti, ki so sledili Forrerju in Ahhiyawo enačili z mikenskim svetom, so Ahhiyawo postavljali v celinsko Grčijo, na Kreto, Dodekaneze, v Jonijo in Karijo, Troado, na Ciper in v Kilikijo. Nasprotniki povezave med Mikenci in Ahhiyawo so Ahhiyawo postavljali v Pamfilijo, Kilikijo in Troado, včasih z razširitvijo na polotok Gallipoli in turško Trakijo. ${ }^{5}$ Danes se zdi identifikacija Ahhiyawe $\mathrm{z}$ mikenskim svetom na splošno sprejeta. ${ }^{6}$

Poleg krajevnega imena Ahhiyawa so hetitski teksti ohranili še nekaj imen, ki jih znanstveniki danes povezujejo z naselitvenim področjem ali vplivom Mikencev v bronasti dobi: Apaša (Efez), Lazpa (Lesbos), Millawanda/ Milawata (Milet). ${ }^{7}$ Za proučevanje stikov Mikencev in Hetitov je pomembna predvsem identifikacija Millawande in Mileta, hetitski teksti namreč pripovedujejo o več vojaških spopadih na tem področju.

4 Gl. Forrer, »Die Griechen in den Boghazköi-Texten«, »Vorhomerische Griechen in den Keilschrifttexten von Boghkazköi«; podobnost med imenoma Ahhiyawa in Ahajci je sicer omenil že Götze, »Kleinasien zur Hethiterzeit«, 26.

5 Za pregled in nadaljnjo literaturo gl. Niemeier, "The Mycenaeans in Western Anatolia«, 20 s., Fischer, Die Ahhiyawa-Frage.

6 Bryce, »Ahhiyawans and Mycenaeans«, »The Nature of Mycanaean Involvement«, »Relations Between Hatti and Ahhiyawa«; Cline, Sailing the Wine-Dark Sea, 49; Hawkins, »Tarkasnawa King of Mira«, 30 s.; Mee, "Anatolia and the Aegean in the Late Bronze Age«, 142; Mountjoy, "The East Aegean-West Anatolian Interface«, 47-51; Niemeier, "The Mycenaeans in Western Anatolia«, 19-25; Horvat, "Stiki Hetitov z egejskimi ljudstvi«; Beckman, Bryce in Cline, The Ahhiyawa Texts; izjema Starke, »Troia im Kontext des historisch-politischen und sprachlichen Umfeldes«.

7 Gl. Bryce, The Routledge Handbook of The Peoples and Places, 49, 415 s., 472 ss. Za identifikacijo Millawande in Mileta gl.: Hrozný, »Hethiter und Griechen«, 329; Hawkins, »Tarkasnawa King of Mira«, 30; Niemeier, »Hattusa und Ahhiyawa im Konflikt um Millawanda/Milet«, 296. Nekateri znanstveniki so Millawando postavljali v deželo Milyas ali na kilikijsko obalo (za pregled in nadaljnjo literaturo gl. Niemeier, »The Mycenaeans in Western Anatolia«, 21 ss.). 


\section{AHHIYAWA TEKSTI}

Prvo izdajo hetitskih besedil z omembami krajevnega imena Ahhiyawa je 1932. leta pripravil F. Sommer v delu z naslovom Die Ahhijavā Urkunden. Najsodobnejšo študijo Ahhiyawa besedil, ki poleg 26 že dalj časa znanih hetitskih tekstov vključuje še dve pismi v akadščini in dvojezični feničansko-luvijski napis $\mathrm{v}$ anatolskih hieroglifih, pa je pripravil G. Beckman. ${ }^{8}$ Ta besedila sodijo $\mathrm{v}$ različne žanre (uvrščamo jih med inventarje, pisma, orakularna povpraševanja, molitve, pogodbe, zgodovinske propagandistične pripovedi, anale in napise) in so večinoma nastala med poznim 15. in koncem 13. stol. pr. n. št. Nazadnje je Ahhiyawa (natančneje Hiyawa) ${ }^{9}$ omenjena v luvijski različici feničansko-luvijskega napisa kralja Awarikuš (akadsko Warika) iz srednjega ali poznega 8. stol. pr. n. št., kjer označuje kraljestvo v južni Anatoliji.

Številni Ahhiyawa teksti so fragmentarni in pogosto nejasni, neznan ostaja tudi natančen čas njihovega nastanka: $\mathrm{z}$ gotovostjo je v vladavino posameznih hetitskih kraljev mogoče datirati le 8 tekstov, pri 12 je avtorstvo verjetno, 9 je mogoče uvrstiti le v določeno stoletje; 22 izmed teh besedil sodi v 13. stol. pr. n. št. ${ }^{10}$ Kljub temu so kot zgodovinski vir o deželi Ahhiyawa v bronasti dobi izredno pomembni. Razen morebitne omembe Ahhiyawe med "pomorskimi ljudstvi« na napisu v Karnaku faraona Merneptaha o Ahhiyawi izven hetitskih virov ni jasnih omemb. Ne omenjajo se na napisih velikih sil Bližnjega vzhoda, tudi dokazov o komunikaciji kralja Ahhiyawe z drugimi silami Bližnjega vzhoda ni. ${ }^{11}$

Ahhiyawa (natančneje kralj Ahhiyawe) je v fragmentarnem kontekstu prvič izpričana $\mathrm{v}$ zapisu orakularnega povpraševanja ${ }^{12} \mathrm{~s}$ konca 15 . ali z začetka 14. stol. pr. n. št. ${ }^{13}$ Drugič je omenjena v Obtožbi Madduwatte, ${ }^{14}$ kjer (med drugim) izvemo o konfliktu Madduwatte z Attariššiyo/Attaršiyo, možem Ahhiye. ${ }^{15}$ Attarišiya je Madduwatto pregnal iz njegove domovine in ta se je po zaščito zatekel k hetitskemu kralju. Tudhaliya I/II ga je sprejel in postavil za svojega vazala. Nato je Madduwatta napadel Arzawo, Hattiju že dalj časa so-

8 Gl. Beckman, Bryce in Cline, The Ahhiyawa Texts. G. Beckman je pripravil nove transliteracije, prevode, kratke stvarne uvode in komentarje. T. Bryce je pripravil komentarje, ki tekste postavljajo v širši zgodovinski in interpretativni okvir. E. H. Cline je odgovoren za predgovor, uvod, končni esej, nadzorovanje delovnega procesa in pripravo publikacije. Knjiga je opremljena še z zemljevidom Anatolije, severne Sirije in severne Mezopotamije ter z zemljevidom Grčije in zahodne Anatolije v pozni bronasti dobi, s preglednico Ahhiyawa besedil v približnem kronološkem zaporedju in s preglednico hetitskih vladarjev v novem kraljestvu.

9 Ime Hiyawa je nastalo po afajrezi iz "Ahhiyawa«, gl. Bryce, The Routledge Handbook of The Peoples and Places, 11.

10 Pri kronološki predstavitvi tekstov in datacijah sledim delu Beckman, Bryce in Cline, The Ahhiyawa Texts, $7 \mathrm{~s}$.

11 Bryce, »Relations Between Hatti and Ahhiyawa«, 65.

12 CTH 571.2, KBo $16.97+$ KBo 40.48.

13 Drugi teksti, v katerih se ime Ahhiyawa pojavlja v slabo razumljivem kontekstu, v nadaljevanju niso obravnavani.

14 CTH 147, KUB 14.1 + KBo 19.38.

15 Starejša oblika za »mož Ahhiyawe«. 
vražno deželo. ${ }^{16}$ Tudi v tem boju je bil poražen in hetitski kralj mu je poslal vojaško pomoč. Ko je Attarišiya Madduwatto še drugič napadel, je Madduwatta spet zbežal in hetitska vojska je napadalca spet premagala. Attarišiya se je umaknil in vrnil v svojo deželo, morda v jugozahodni Anatoliji. ${ }^{17}$ Kasneje v istem besedilu izvemo, da sta Madduwatta in Attarišiya skupaj napadla Alašiyo (Ciper), ki je pripadala Hetitom. To je prvi neposredni vir o vojaški dejavnosti Ahhiyawe na področju zahodne Anatolije in Cipra z začetkom ok. 1430 pr. n. št., ${ }^{18}$ ki kaže, da je imel Attarišiya poleg kopenske vojske (obsegala je približno 100 bojnih vozov in pehoto) tudi učinkovito pomorsko enoto.

Sovražnost med Ahhiyawo in Hetiti se je skozi 14. stol. pr. n. št. očitno nadaljevala. Anali Muršilija $\mathrm{II}^{19}$ iz poznega 14. stol. pr. n. št. namreč pripovedujejo, da so Ahhiyawa, Arzawa in Milawanda v tretjem letu Muršilijeve vladavine sklenile zavezništvo, Muršili je odposlal vojsko in Millawanda je bila ok. 1320 uničena. ${ }^{20}$ Potem ko je Muršili porazil Uhhazitija, kralja Arzawe, je ta z družino in drugimi zbežal na otoke Ahhiyawe, predvidoma v vzhodnem Egejskem morju. ${ }^{21}$ Uhhazitijev sin Tapalazunawili se je na zahodno obalo Anatolije vrnil, bil poražen in še enkrat zbežal h kralju Ahhiyawe.

V kasnejših tekstih izvemo, da so ritualisti boga Ahhiyawe nekako vključili v zdravljenje Muršilija II, ${ }^{22}$ da je bila v Ahhiyawo izgnana neka hetitska kraljica $^{23}$ in da sta se kralja Hattija in Ahhiyawe nekje med sredino 14. in začetkom 13. stol. pr. n. št. dogovarjala o izročitvi ali repatriaciji hetitskih podanikov. ${ }^{24}$ Ti podatki implicirajo, da so bili po hetitskem uničenju Millawande in $\mathrm{v}$ času nastanka teh besedil odnosi med Hattijem in Ahhiyawo miroljubni in da sta državi sklenili neke vrste diplomatski dogovor, ${ }^{25}$ morda celo pogodbo. ${ }^{26}$

Do zgodnjega 13. stol. pr. n. št. je Ahhiyawa vsekakor spet imela oblast nad Millawando, od tam pa je svoj vpliv širila drugod po Anatoliji. ${ }^{27} \mathrm{~V}$ začetku 13. stol. pr. n. št. je Ahhiyawa tako podpirala Hattiju nenaklonjenega Piyamaraduja, verjetno Uhhazitijevega vnuka, ki je Hetitom, njihovim vazalom

16 Kraljestvo Arzawa z glavnim mesto Apaša (Efez) je bilo locirano v zahodni Anatoliji; nekateri znanstveniki ga ločujejo od pokrajine $\mathrm{z}$ istim imenom, ki je verjetno združevala več manjših kraljestev (gl. Bryce, The Routledge Handbook of The Peoples and Places, 49, 74).

17 Gl. Niemeier, »Mycenaeans and Hittites in War in Western Asia Minor «, 147.

18 Bryce, The Routledge Handbook of The Peoples and Places, 83, prve vojaške posege Ahhiyawe v Anatoliji postavlja v čas, ko so Hetiti zatrli upor v Aššuwi. Aššuwa je področje v zahodni Anatoliji. V analih hetitskega kralja Tudhaliye I/II iz zgodnjega 14. stol. pr. n. št. Aššuwa označuje koalicijo dvaindvajsetih dežel, ki se je deželi Hatti uprla in bila poražena.

19 CTH 61.I, različica A KBo 3.4 + KUB 23.125, različica B KBo 16.1+ KUB 31.137 + KBo 16.2 (+) KBo 44.239 (+) KBo 44.2, različica C KUB 19.38 (+) KUB 14.21; CTH 61.II, različica A KUB 14.15 + KBo 16.104, različica B KUB 14.16, različica C KBo 16.5 + KUB 19.40, različica D KBo 12.37.

20 Gl. Bryce, The Routledge Handbook of The Peoples and Places, 474.

21 Gl. Bryce, »Ahhiyawans and Mycenaeans«, 300.

22 CTH 570.1, KUB 5.6 + KUB 18.54 + KBo 53.103 (+) KUB 50.123.

23 CTH 214.12.A, KUB 14.2.

24 CTH 209.16, KUB 23.95, o tem gl. Beckman, Bryce in Cline, The Ahhiyawa Texts, 152.

25 Beckman, Bryce in Cline, The Ahhiyawa Texts, 273.

26 Košak, »The Hittites and the Greeks«, 41.

27 O tem priča t.i. Tawagalawa pismo, gl. spodaj. 
in zaveznikom kar nekaj desetletij povzročal težave v zahodni Anatoliji. ${ }^{28} \mathrm{~V}$ približno istem času je zavzela tudi nekaj otokov, predvidoma v Egejskem morju, ${ }^{29}$ o čemer je mogoče sklepati iz fragmentarnega pisma kralja Ahhiyawe hetitskemu kralju. ${ }^{30}$ Ker je ogrožala zahodne vazalne države hetitskega kraljestva, je Hattušili III ${ }^{31}$ kralju Ahhiyawe v sredini 13. stol. pr. n. št. očital podpiranje protihetitskih posegov v zahodni Anatoliji in zahteval pomoč pri ponovni vzpostavitvi miru. V pismu Hattušilija III tako spet izvemo o Piyamaradujevih neprestanih napadih na hetitske vazalne države, pa tudi da je oblast nad Millawando v tem času v rokah Atpe, verjetno Piyamaradujevega zeta. ${ }^{32}$ Pismo je kljub očitkom napisano v spravljivem tonu, v njem Hattušili III kralja Ahhiyawe celo nagovarja kot svojega brata in vrstnika. ${ }^{33} \mathrm{~S}$ tem nagovorom so »veliki kralji« bližnjega vzhoda (Egipta, Asirije, Babilona, Hattija) sicer priznavali medsebojno diplomatsko enakovrednost. ${ }^{34}$ Del »bratske« politike je bila tudi izmenjava diplomatskih darov; vzklik Hattušilija III »tvoj sel mi ni prinesel darov v pozdrav « ${ }^{35}$ pa kaže, da je bil kralj Ahhiyawe pri spoštovanju te prakse okoren ali namerno ignorantski. $\mathrm{V}$ istem besedilu namreč izvemo tudi o »izmenjavi« delovne sile, to je o nekaj tisoč ljudeh iz zahodne Anatolije, ki so jih (morda tudi prisilno) naselili na področju Ahhiyawe. S problematiko diplomatskih darov se kasneje ukvarja tudi pismo kraljevega podanika hetitskemu kralju, v katerem sprašuje, ali sta srebrna in zlata čaša primerna darova za kralja Ahhiyawe. ${ }^{36} \mathrm{Na}$ diplomatske kontakte in neko vrsto dogovora glede mej med Hattijem in Ahhiyawo bi lahko nakazoval tudi fragmentarno ohranjen dokument, ki vključuje popis mej držav v zahodni Anatoliji in omenja Ahhiyawo, ${ }^{37}$ vendar interpretacija tega besedila ni gotova. ${ }^{38}$

$\mathrm{V}$ srednjem ali poznem 13. stol. pr. n. št. se je po pomoč in podporo $h$ kralju Ahhiyawe obrnil legalni hetitski prestolonaslednik Urhi-Teššup, čigar prestol je uzurpiral Hattušili III. Iz odlomka pisma hetitskega kralja ${ }^{39}$ je mogoče razbrati, da kralj Ahhiyawe legalnemu prestolonasledniku ni pomagal. A prohetitsko delovanje ni trajalo dolgo, saj v razglasu velikega kralja dežele Hatti iz konca 13. stol. pr. n. št. ${ }^{40}$ spet izvemo, da je kralj Ahhiyawe v zahodni

28 O Piyamaradujevih podvigih prvič izvemo v pismu hetitskega vazala Manapa-Tarhunte (CTH 191, KUB 19.5 + KBo 19.79) iz zgodnjega 13. stol. pr. n. št.

29 Gl. Kelder, The Kingdom of Mycenae, 26.

30 CTH 183, KUB 26.91.

31 CTH 181, KUB 14.3. Za datacijo gl. Singer, "Western Anatolia in the Thirtheenth Century BC«, 209 s.; Ünal, »Two Peoples on Both Sides of the Aegean Sea«, 33 s., in Gurney, »The Authorship of the Tawagalawa Letter«, Tawagalawa pismo datirata v čas Muwatallija II (1295-1272), vendar ta teza doslej ni splošno sprejeta.

32 Bryce, »Ahhiyawans and Mycenaeans«, 302.

33 O tem gl. Güterbock, »Hittites and Akhaeans«, »The Hittites and the Aegean World «.

$34 \mathrm{Za}$ razlago nepričakovane rabe tega naziva in spravljiv ton celotnega pisma $\mathrm{z}$ vidika politične situacije v času Hattušilija III gl. Bryce, "Relations Between Hatti and Ahhiyawa«, 66f ss., kjer avtor opozarja, da Ahhiyawa z vidika drugih velikih sil Bližnjega vzhoda ni bila nikdar razumljena kot velika sila.

35 CTH 181, KUB 14.3 Ro i 54 s., gl. tudi Kelder, "Mycenaeans in Western Anatolia«, 78.

36 CTH 209.12, KBo 2.11, sredina 13. stol. pr. n. št.

37 CTH 214.16, KUB 31.12, sredina ali pozno 13. stol. pr. n. št.

38 Gl. Beckman, Bryce in Cline, The Ahhiyawa Texts, $174 \mathrm{~s}$.

39 CTH 214.12.C, KBo 16.22.

40 CTH 211.4, KUB 23.13. 
Anatoliji podpiral Tarhuntaraduja, ki si je prizadeval za oblast v vazalni deželi Hetitov reke Šeha in zanetil protihetitski upor. Morda je prav ta ponovna »izdaja « Tuhaliyo IV, sina Hattušilija III, spodbudila k zadnjemu in odločilnemu spopadu s silo Ahhiyawe. ${ }^{41}$

Ker si je Tudhaliya IV močno prizadeval za obnovitev oblasti na obalah Anatolije, je tako naposled zavzel Millawando in Ahhiyawa je s tem izgubila izhodišče za nadaljnje posege $\mathrm{v}$ zahodno Anatolijo in center moči na tem področju, zato njena izguba pomeni konec vpliva Ahhiyawe v zahodni Anatoliji. ${ }^{42}$ Sledilo je ponovno določanje mej in naslovnik pisma hetitskega kralja (verjetno Atpa, prvotno vazal Ahhiyawe) ${ }^{43}$ je bil postavljen za hetitskega vazala. ${ }^{44} \mathrm{Z}$ izgubo Millawande je kralj Ahhiyawe tudi izgubil status velikega kralja. V pogodbi Tudhaliye IV z vazalom Šauškamuwo, ${ }^{45}$ vladarjem obalne države Amurru v Siriji, je kralj Ahhiyawe tako najprej naveden med hetitskemu kralju enakovrednimi vladarji, nato pa je pisar njegovo omembo v seznamu prečrtal.

Možje Hiyawe so kmalu zatem, v času vladavine zadnjega hetitskega kralja Šuppiluliume II (1207-), omenjeni še v dveh pismih, ${ }^{46}$ ki se tičeta neke pošiljke (morda kovinskih ingotov). ${ }^{47}$ Možno je, da je bila omenjena pošiljka plačilo za službo v vojski. ${ }^{48}$

\section{ARHEOLOŠKI VIRI}

Prve mikenske najdbe na egejskih otokih (Rodosu, Kosu, Lezbosu in Kalimnosu) je mogoče datirati v konec 15. stol. pr. n. št., med 1375 in 1300 pr. n. št. se pojavijo na Astipalaji in Lemnosu, na Hiosu po 1300 pr. n. št. ${ }^{49}$ Po zahodni anatolski obali so raztresene med koncem 15. in 12. stol. pr. n. št.; najbolj številne pa so mikenske najdbe na tem področju v obdobju med 1375 in 1230 pr. n. št., saj izvirajo iz več kot dvanajstih najdišč. Po količini in raznolikosti najdenih predmetov (keramika, kipci in kovinski predmeti) in po časovnem razponu izstopajo najdišča Milet, Troja, Efez (z okolico) in Müsgebi. ${ }^{50}$

41 Beckman, Bryce in Cline, The Ahhiyawa Texts, 157.

42 Bryce, The Routledge Handbook of The Peoples and Places, 474.

43 Gl. Bryce, »Ahhiyawans and Mycenaeans«, 304.

$44 \mathrm{O}$ tem pripoveduje t.i. Milawata-pismo iz poznega 13. stol. pr. n. št. (CTH 182, KUB 19.55 + KUB 48.90).

45 CTH 105, različica A 93/w (+) KUB $23.1+$ KUB 31.43 (+) KUB 23.37 (+) 720/v (+) 670/v, različica B $1198 / \mathrm{u}+1436 / \mathrm{u}+69 / 821+$ KUB 8.82, pozno 13. stol. pr. n. št.

46 RS 94.2530, RS 94.2523

47 Singer, »Ships Bound for Lukka«, 252-58.

48 Tako Bryce, "The Hittite Deal with the Hiyawa-Men«, 51 s. Lackenbacher in Malbran-Labat, »Ugarit et les Hittites dans les archives«, 238, menita, da gre za najemniško vojsko ali za najeto delovno silo, Singer, »Ships Bound for Lukka«, 252, da gre za trgovce ali predstavnike Ahhiyawe.

49 Mountjoy, »The East Aegean-West Anatolian Interface«, 34.

50 Kelder, The Kingdom of Mycenae, 52. Najstarejše najdbe so iz Mileta in Klazomen, gl. Mee, "Anatolia and the Aegean in the Late Bronze Age«, 137; Kelder, "Mycenaeans in Western Anatolia«, 72 s., The Kingdom of Mycenae, 54 s., 131 s. Za študije mikenskih predmetov v Anatoliji gl. Mee, "Aegean Trade and Settlement in Anatolia ", "Anatolia and the Aegean in the Late Bronze Age«; Kelder, "Mycenaeans in Western Anatolia«, The Kingdom of Mycenae, 121-36, 140. 
Najpomembnejše je najdišče $v$ Miletu, ki kaže širok spekter mikenskih značilnosti in predmetov od obdobja $1450-1400$ pr. n. št. naprej. Žgalne peči, hiše, kipci in keramika, pa tudi grobnice $1.5 \mathrm{~km}$ jugozahodno od Mileta (Değirmentepe) kažejo na obstoj mikenske naselbine $\mathrm{v}$ času med 1425 in 1300. V poznem 14. ali zgodnjem 13. stol. pr. n. št. je Milet uničil ogenj, kmalu zatem pa je bil obnovljen in obdan z obzidjem. Enakomerno razporejeni štirioglati obrambni stolpi in navzkrižni zidovi kažejo hetitske vplive. ${ }^{51}$ Analiza keramike iz 13. stol. pr. n. št. (95\% mikenskega in 5\% anatolskega izvora) vseeno kaže prevladujoči mikenski element, očitno je bila večina mikenske keramike proizvedena lokalno. ${ }^{52}$ Arheološko je pozicija Mileta kot pomembnega centra mikenske kulture v Anatoliji torej potrjena, ${ }^{53}$ na stike s Hetiti pa kaže na primer še mikenska črepinja s sliko hetitskega pokrivala ali kraljeve tiare..$^{54}$

Medtem ko se število mikenskih predmetov, predvsem keramike, ob obalah zahodne Anatolije med začetkom 14. in koncem 13. stol. pr. n. št. povečuje, so mikenske najdbe v osrednji Anatoliji redke. Edino najdišče z večjimi količinami mikenske keramike je Maşat (het. Tapikka), vendar ta keramika morda izhaja iz časa, ko mesto ni bilo pod hetitsko oblastjo. ${ }^{55}$ Hetitska prestolnica Hattuša (današnji Bögazköy) je do danes ohranila le tri mikenske predmete: pas, črepinjo posode s podobo mikenskega vojščaka in bronast meč. ${ }^{56}$ Akadski napis na rezilu meča sporoča, da ga je Gromovniku po zmagi nad Aššuwo posvetil hetitski kralj Tudhaliya I/II $;^{57}$ meč verjetno sodi med plen, pridobljen na tem pohodu. ${ }^{58}$ Črepinjo iz Boğazköya je mogoče datirati okrog 1400 pr. n. št., meč v 2. polovico ali konec 15. stol. pr. n. št., zato ju mnogi znanstveniki interpretirajo kot prvi posredni dokaz o vojaški aktivnosti Mikencev na področju Anatolije. ${ }^{59}$ Najdbe mikenskih predmetov v osrednji Anatoliji sicer vključujejo še posodo in nož v Fraktinu ter črepinje na najdiščih Gödelesin Höyük in Üç Höyük. ${ }^{60}$

Avtor doslej edine študije hetitskih najdb na področju Egejskega morja E. H. Cline ugotavlja, da je izmed 942 uvoženih najdb bronaste dobe anatolski/

51 Mee, »Aegean Trade and Settlement in Anatolia«, 135, 149, »Anatolia and the Aegean in the Late Bronze Age«, 139; Kelder, The Kingdom of Mycenae, 52. Te najdbe kažejo na kratko tranzicijo Mileta iz rok Mikencev v roke Hattija, gl. npr. Niemeier, »Mycenaeans and Hittites in War in Western Asia Minor«, 153.

52 Gl. Mee, "Anatolia and the Aegean in the Late Bronze Age«, 139, za nadaljnje reference.

53 Gl. Kelder, "Mycenaeans in Western Anatolia«, 72-75, The Kingdom of Mycenae, 52, 132.

54 Cline, Sailing the Wine-Dark Sea, 70.

55 Gl. Niemeier, »The Mycenaeans in Western Anatolia«, 45 in ibid. za nadaljnjo literaturo.

56 Gl. Niemeier, »Mycenaeans and Hittites in War in Western Asia Minor«, 150, Cline »Hittite Objects in the Bronze Age Aegean«.

57 Gl. Ünal, »Two Peoples on Both Sides of the Aegean Sea«. V mikenski izvor meča je podvomil Taracha, »Is Tuthaliya’s Sword Really Aegean?«, vendar znanstvena srenja njegove interpretacije ni sprejela, gl. Genz, »Foreign Contacts of the Hittites«, 304 ss.

58 Niemeier, »Mycenaeans and Hittites in War in Western Asia Minor«, 150.

59 Niemeier, »The Mycenaeans in Western Anatolia«, 42 s; Kelder, The Kingdom of Mycenae, 54, Beckman, Bryce in Cline, The Ahhiyawa Texts, $269 \mathrm{~s}$.

60 Gl. Mee, "Aegean Trade and Settlement in Anatolia", 150, "Anatolia and the Aegean in the Late Bronze Age«, 141, Cline, »Hittite Objects in the Bronze Age Aegean«. 
hetitski izvor mogoče pripisati le dvanajstim predmetom. Na področju Egejskega morja odkriti hetitski predmeti tako obsegajo zgolj en odstotek v bronasti dobi z Bližnjega vzhoda ali Orienta uvoženih predmetov. Ti so raztreseni tako skozi čas (datirani so približno med 2000 in 1150 pr. n. št.) kot tudi prostor (najdeni so bili od celinske Grčije do Rodosa; na področju celinske Grčije so bili odkriti le štirje, od tega trije v Mikenah). Raznoliki so tudi materiali (keramika, kamen, plemenite kovine) in njihov namen. Gre namreč za cilindrične pečate, pečatne odtise, bule, kipec sfinge, srebrno čašo v obliki jelena, srebrni kipec »boga kovača « in zlato sponko. ${ }^{61} \mathrm{Ob}$ spoznanju, da je predmete iz osrednje Anatolije na področju Bližnjega vzhoda skoraj tako težko najti kot v Egejskem morju, zgoraj predstavljeno dejstvo morda ni presenetljivo. Hetiti so namreč pustili malo materialnih dokazov o svoji navzočnosti celo na področjih, ki so bila pod njihovim nadzorom, npr. v severni Siriji in (morda) na Cipru. ${ }^{62}$

Omenja se, da so hetitski vplivi segli celo do celinske Grčije. W.-D. Niemeier tako navaja, da je monumentalni kamniti relief levjih vrat v Mikenah narejen pod vplivom hetitske umetnosti in da so bili hetitski prototipi zgled za kiklopske zidove mikenskih palač, kar je še posebej očitno pri podzemnih hodnikih in Kastenmauer konstrukciji v Tirinsu. ${ }^{63}$ Ti vplivi so Mikence seveda lahko dosegli direktno iz osrednje Anatolije ali posredno preko zahodne Anatolije in Kilikije. ${ }^{64}$

Ker so bili mikenski trgovci in izdelki v vzhodnem Sredozemlju dobro znani, mikenske najdbe v osrednji Anatoliji pa maloštevilne, je E. H. Cline predpostavil, da so Hetiti mikensko trgovsko aktivnost v svoji državi preprečili $\mathrm{Z}$ embargom. Možno je seveda tudi trgovanje s pokvarljivim ali »nevidnim«blagom in surovinami, ki ni pustilo vidnih arheoloških sledi. Na takšno trgovanje bi lahko namigovale na južni in zahodni obali Anatolije odkrite in pogosto za transport vina, olivnega olja, dišav idr. rabljene zaprte posode. Ker te posode niso bile primerne za kopensko pot do prestolnice Hattuše, bi tržno blago lahko presipali v primernejšo embalažo, na primer v usnjene vreče ali torbe. ${ }^{65}$

61 Cline, "Hittite Objects in the Bronze Age Aegean«, Orientalia in the Late Bronze Age Aegean, 141-81, Sailing the Wine-Dark Sea, 68-77, Genz, »Foreign Contacts of the Hittites«, 304 ss. Cline, "A Possible Hittite Embargo Against the Mycenaeans, 1, kot »osrednje anatolske " označi le šest od dvanajstih.

62 Cline, Orientalia in the Late Bronze Age Aegean, 179, Sailing the Wine-Dark Sea, 71.

63 Niemeier, »The Mycenaeans in Western Anatolia«, 43. Na to lahko nakazuje tudi Strabonova omemba (8.6.11.), da so kiklopske zidove Tirinsa zgradili »velikani« iz zahodne Anatolije; o tem Bryce, The Trojans and Their Neighbours, 102. Podatke o delovni sili z vzhoda Egejskega morja hranijo tudi tablice v linearju B iz Pilosa, ki omenjajo tekstilne delavke iz krajev Mi-ra-ti-ja $=$ Milet, $Z e-p u_{2}-r a_{3}=$ Halikarnas, Ki-ni-di-ja $=$ Knid in $A-{ }^{*} 64-j a, A-{ }^{*} 64-j o$ z variacijami $=$ Lidija (Azija); gl. Cline, "A Possible Hittite Embargo Against the Mycenaeans«, 5 s., Orientalia in the Late Bronze Age Aegean, 152, Sailing the Wine-Dark Sea, 68 s., 130 s.; Bryce, The Trojans and Their Neighbours, 102 s.; Kelder, The Kingdom of Mycenae, 6, ki celo meni, da je bilo nabiranje delovne sile ena izmed motivacij za vpade Mikencev v okolico Mileta.

64 Cline, »A Possible Hittite Embargo Against the Mycenaeans«, 2.

65 Cline, »A Possible Hittite Embargo Against the Mycenaeans«, Orientalia in the Late Bronze Age Aegean, 179, Sailing the Wine-Dark Sea, 71-74. 
Takšno interpretacijo je zaradi pomanjkanja varnih cestnih povezav med Hattušo in obalami zahodne Anatolije, zaradi dsotnosti očitne motivacije za dolgotrajni trgovski kontakt med Mikenci in Hetiti in zaradi pomanjkljivih socio-ekonomskih razlogov (mikenski svet bi na Bližnjem vzhodu za Hetite pomenil pomembno in dolgoročno grožnjo, razmerje med deželama Hatti in Ahhiyawa pa bi moralo biti pretežno sovražno) zavrnil T. Bryce. ${ }^{66}$ Bolj verjetno se zdi, da Hetiti z Mikenci niso nikoli direktno trgovali, temveč so imeli dostop do mikenskih predmetov preko posrednikov iz siro-palestinskih obalnih državic. ${ }^{67}$

\section{ALI JE PROBLEM AHHIYAWE REŠEN?}

Analiza Ahhiyawa tekstov in njihova približna kronološka razporeditev torej kažeta, da je bila Ahhiyawa na področju zahodne Anatolije prisotna že konec 15. stol. pr. n. št. Ker večina omenjenih tekstov izvira 13. stol. pr. n. št., je mogoče sklepati, da so bili stiki med obema državama najbolj intenzivni prav v tem času. Hetitsko aspiracijo po politični premoči v zahodni Anatoliji je Ahhiyawa ogrožala s podpiranjem protihetitskih dejavnosti in uporov, $\mathrm{z}$ napadi na različne hetitske vazalne države in $\mathrm{z}$ nudenjem zatočišča svojim zaveznikom ter nasprotnikom hetitske države. Kljub temu da kralji Ahhiyawe niso bili zmeraj uspešni, so bili verjetno dovolj močni, da so (večino časa) nadzorovali vsaj en center na anatolski obali, Millawando. To je okrog 1320 pr. n. št. porušila vojska Muršilija II, kmalu zatem pa je bila Millawanda spet v rokah Ahhiyawe. Dokončna izguba tega izhodišča za širjenje vpliva konec 13. stol. pr. n. št. je pomenila tudi konec vidnejšega delovanja Ahhiyawe v zahodni Anatoliji in na otokih vzhodnega Egejskega morja. Otokov pod vplivom Ahhiyawe ni mogoče vedno identificirati, ponavljajoče se omembe le-teh pa kažejo, da je Ahhiyawa imela znatno moč tudi na morju. Vojaški posegi v osrednjo Anatolijo in do meja hetitske države v tekstnih virih niso omenjeni. Kljub pogostim omembam vojaških spopadov pa odnosi med Ahhiyawo in Hattijem gotovo niso bili sovražni skozi vse obdobje njune interakcije. Več tekstov namreč priča tudi o diplomatskih in miroljubnih stikih med državama, možje Hiyawe so v času zadnjega hetitskega kralja konec 12. stol. pr. n. št. verjetno delovali celo kot hetitska najemniška vojska.

Prisotnost Mikencev v zahodni Anatoliji in na egejskih otokih med koncem 15. in 12. stol. pr. n. št. potrjujejo arheološki viri, najštevilčnejše pa so

66 Bryce, »Relations Between Hatti and Ahhiyawa«.

67 Bryce, "Relations Between Hatti and Ahhiyawa«, 6o, »The Hittite Deal with the Hiyawa-Men«, 48; gl. tudi Taracha, »Mycenaeans in Anatolia and Ahhiyawa of Hittite Texts«. Za skromne podatke o trgovcih pri Hetitih gl. Klengel, »Handel und Kaufleute im hethitischen Reich«, Hoffner, 2001, »Some Thoughts on Merchants and Trade in the Hittite Kingdom«, Bryce, Life and Society in the Hittite World, 87-97, za širšo problematiko trgovanja pri Hetitih gl. Genz, „Foreign Contacts of the Hittites«, 323 s. O trgovanju Mikencev gl. Kelder, The Kingdom of Mycenae, 58 ss. 
mikenske najdbe na tem področju v 13. stol. pr. n. št. Začetke vojaške aktivnosti Mikencev v zahodni Anatoliji morda nakazujeta v Hattuši odkriti meč in črepinja s podobo mikenskega vojaka iz 2. polovice 15. ali z začetka 14. stol. pr. n. št., vsekakor o spopadu med Hetiti in Mikenci pričajo sledovi ognja in porušenja $\mathrm{v}$ Miletu (takrat že mikenski naselbini) s konca 14. ali z začetka 13. stol. pr. n. št. in zatem zgrajeno obzidje z značilnostmi hetitske arhitekture. Da je Milet kmalu spet postal mikenski, dokazuje pretežno mikenska keramika v 13. stol. pr. n. št. Pomanjkanje mikenskih najdb v osrednji Anatoliji morda odseva meje mikenske vojaške aktivnosti v Anatoliji, in nakazuje, da direktnih trgovskih stikov med Mikenci in Hetiti ni bilo. O diplomatskih stikih med Mikenci in Hetiti na osnovi maloštevilnih arheoloških najdb ni mogoče sklepati.

Stiki med Mikenci in Hetiti so torej arheološko potrjeni. Na vprašanje, ali je Ahhiyawo v hetitskih tekstih mogoče enačiti z mikenskim svetom, pa je na osnovi posrednih dokazov, t.j. korelacije tekstnih virov o Ahhiyawi in arheoloških virov o Mikencih, mogoče odgovoriti pritrdilno. Hkrati z identifikacijo pa so se odprla naslednja vprašanja. Ali se omembe Ahhiyawe nanašajo na celinsko Grčijo, celotno področje mikenske poselitve, posamezno mestno državo in/ ali od te politično ali vojaško odvisna področja? Ali hetitski pisni viri kažejo na zvezo mikenskih državic ali posamezne centre mikenske kulture? Ali se hetitska percepcija kralja Ahhiyawe kot »velikega kralja« ujema $\mathrm{z}$ njegovo percepcijo $\mathrm{v}$ hierarhiji mikenskega sveta? Ali lahko hetitski teksti informirajo o politični organizaciji Mikencev? Se je pomen tega imena skozi čas spreminjal? Ali je problem Ahhiyawe rešen? Odgovore na ta vprašanja lahko morda nudi interdisciplinarna študija in interpretacija mikenskih, hetitskih tekstnih in arheoloških virov, kakor jo je zasnoval J. Kelder v delu The Kingdom of Mycenae: A Great Kingdom in the Late Bronze Age Aegean. Na njene odmeve pa je treba še počakati.

\section{BIBLIOGRAFIJA}

Beckman, G. M., T. R. Bryce in E. H. Cline. The Ahhiyawa Texts. Writings from the Ancient World 28. Atlanta: Society of Biblical Literature, 2011.

Bryce, T. "A reinterpretation of the Milawata Letter in the Light of the New Join Piece.« Anatolian Studies 35 (1985): 13-23.

_. "Ahhiyawans and Mycenaeans-an Anatolian Viewpoint." Oxford Journal of Archeology 7 (1988): 297-310.

»The Nature of Mycanaean Involvement in Western Anatolia. « Historia 38 (1989): 1-21.

Life and Society in the Hittite World. Oxford: Oxford University Press, 2002.

- "Relations Between Hatti and Ahhiyawa in the Last Decades of the Bronze Age.« V: G. Beckman, R. Beal in G. McMahon, ur., Hittite Studies in Honor of Harry A. Hoffner Jr. on the Occasion of His 65th Birthday, 59-72. Winona Lake: Eisenbrauns, 2003. 
- The Trojans and Their Neighbours. London in New York: Routledge, 2006.

»The Hittite Deal with the Hiyawa-Men.« V: Y. Cohen, A. Gilam in J.

L. Miller, ur., Pax Hethitica: Studies on the Hittites and Their Neighbours in Honour of Itamar Singer, 47-53. Studien zu den BoğazköyTexten 51. Wiesbaden: Harrassowitz, 2010.

- The Routledge Handbook of The Peoples and Places of Ancient Western Asia: The Near East from the Early Bronze Age to the Fall of the Persian Empire. London in New York: Routledge, 2012.

Cline, E. H. »A Possible Hittite Embargo Against the Mycenaeans. « Historia 40 (1991a): 1-9.

—. "Hittite Objects in the Bronze Age Aegean.« Anatolian Studies 41 (1991b): 133-43.

- Orientalia in the Late Bronze Age Aegean. Rokopisna disertacija. University of Pennsylvania, 1991c.

- Sailing the Wine-Dark Sea: International Trade and the Late Bronze Age Aegean. BAR S591. TEMPVS REPARATVM: Oxford, 1994.

Collins, B. J. The Hittites and Their World. Archeology and Biblical Studies 7. Atlanta: Society of Biblical Literature, 2008.

Fischer, R. Die Ahhiyawa-Frage. Dresdner Beiträge zur Hethitologie 26. Wiesbaden: Harrassowitz, 2010.

Forrer, E. »Die Griechen in den Boghazköi-Texten.« Orientalistische Literaturzeitung 27 (1924a): 113-18.

—. "Vorhomerische Griechen in den Keilschrifttexten von Boghkazköi.« Mitteilungen der deutschen Orient-Gesellschaft 63 (1924b): 1-22.

Genz, H. »Foreign Contacts of the Hittites. « V: H. Genz in D. P. Mielke, ur., Insights into Hittite History and Archeology, 301-31. Colloquia Antiqua 2. Leuven, Paris in Walpole, MA: Peeters, 2011.

Götze, Albrecht. »Kleinasien zur Hethiterzeit." Orient und Antike 1 (1924): $3-32$.

Gurney, O. R. »The Authorship of the Tawagalawa Letter.« V: P. Taracha, ur., Silva Anatolica: Anatolian Studies Presented to Maciej Popko on the Occasion of His 65th Birthday, 133-41. Varšava: AGADE, 2002.

Güterbock, H. G. »Hittites and Akhaeans: A New Look.» V: H. A. Hoffner in I. L. Diamond, ur., Perspectives on Hittite Civilisation: Selected Writings of Hans Gustav Güterbock, 205-10. Assyriological Studies 26. Chicago: The Oriental Institute, 1997a.

»The Hittites and the Aegean World: Part 1. The Ahhiyawa Problem Reconsidered.« V: H. A. Hoffner in I. L. Diamond, ur., Perspectives on Hittite Civilisation: Selected Writings of Hans Gustav Güterbock, 199204. Assyriological Studies 26. Chicago: The Oriental Institute, 1997b.

Hawkins, J. D. »Tarkasnawa King of Mira: 'Tarkondemos', Boğazköy sealings and Karabel.» Anatolian Studies 48 (1998): 1-31. 
Hoffner, H. A. "Some Thoughts on Merchants and Trade in the Hittite Kingdom.« V: T. Richter, D. Prechtel in J. Klinger, ur., Kulturgeschichten: Altorientalistische Studien für Volkert Haas zum 65. Geburtstag, 179-89. Saarbrücken: SDV Saarbrücker, 2001.

Horvat, M. »Stiki Hetitov z egejskimi ljudstvi.« Keria 5 (2003): 69-80.

Hrozný, B. »Hethiter und Griechen.« Archiv Orientální 1 (1929): 323-43.

Kelder, J. M. »Mycenaeans in Western Anatolia.« Talanta 36-37 (2004-2005): 49-86.

- The Kingdom of Mycenae: A Great Kingdom in the Late Bronze Age Aegean. Bethesda, MD: CDL Press, 2010.

Klengel, H. »Handel und Kaufleute im hethitischen Reich."Altorientalische Forschungen 6 (1979): 165-74.

Košak, S. »The Hittites and the Greeks. « Linguistica 20 (1980): 35-48.

Lackenbacher, S., in F. Malbran-Labat. »Ugarit et les Hittites dans les archives de la „Maison d'Urtenu.“" Studi Micenei ed Egeo-Anatolici 46 (2005): 227-40.

Mee, C. "Aegean Trade and Settlement in Anatolia in the Second Millenium B.C. « Anatolian Studies 28 (1978): 121-56.

—. "Anatolia and the Aegean in the Late Bronze Age."V: E. H. Cline in D. Harris-Cline, ur., The Aegean and the Orient in the Second Millennium: Proceedings of the 50th Anniversary Symposium Cincinnati, 1820 April 1997, 137-46. Aegeum 18. Liège: Université de Liège; Austin: University of Texas, 1998.

Mountjoy, P. A. »The East Aegean-West Anatolian Interface in the Late Bronze Age: Mycenaeans and the Kingdom of Ahhiyawa." Anatolian Studies 48 (1998): 33-67.

Niemeier, W.-D. »The Mycenaeans in Western Anatolia and the Problem of the Origins of the Sea People." V: S. Gitin, A. Mazar in E. Stern, Mediterranean Peoples in Transition: Thirteenth to Early Tenth Centuries BCE, 17-65. Jerusalem: Israel Exploration Society, 1998.

"Mycenaeans and Hittites in War in Western Asia Minor.« V: R. Laffineur, Polemos: le contexte guerrier en Égée àl' âge du bronze, 141-55. Aegaeum 19. Liège: Université de Liège, 1999.

_ . "Hattusa und Ahhiyawa im Konflikt um Millawanda/Milet.«V: H. Willinghofer in U. Hasekamp, Die Hethiter und ihr Reich; das Volk der 1000 Götter, 294-99. Stuttgart: Theiss, 2002.

Schachermeyr, F. Mykene und das Hethiterreich. Wien: Verlag der Österreichischen Akademie der Wissenschaften, 1986.

Singer, I. »Western Anatolia in the Thirtheenth Century BC According to the Hittite Sources. « Anatolian Studies 35 (1983): 205-17. "Ships Bound for Lukka: A New Interpretation of the Companion Letters RS. 94.2530 and RS 94.2523. « Altorientalische Forschungen 33 (2006): 242-62. 
Sommer, F. Die Ahhijavā Urkunden. München: Verlag der Bayerischen Akademie der Wissenschaften, 1932.

Starke, F. »Troia im Kontext des historisch-politischen und sprachlichen Umfeldes Kleinasiens im 2. Jahrtausend. «Studia Troica 7 (1997): 447-87.

Taracha, P. »Is Tuthaliya’s Sword Really Aegean? « V: G. Beckman, R. Beal in G. McMahon, ur., Hittite Studies in Honor of Harry A. Hoffner Jr. on the Occasion of His 65th Birthday, 367-76. Winona Lake: Eisenbrauns, 2003.

—. "Mycenaeans in Anatolia and Ahhiyawa of Hittite Texts: A Re-assessment." Archeologia 57 (2006): 143-49.

Ünal, A. »Two Peoples on Both Sides of the Aegean Sea: Did the Achaeans and Hittites Know Each Other? "V: Princ Takahito Mikasa, H. I. H., ur., Essays on Ancient Anatolian and Syrian Studies in the 2nd and 1st Millennium BC. Bulletin of the Middle Eastern Culture Center in Japan 4 (1991): 16-44. 